\title{
REVIEW
}

\section{Mesenchymal stromal cells retrovirally transduced with prodrug-converting genes are suitable vehicles for cancer gene therapy}

\author{
E. ĎURINIKOVÁ, L. KUČEROVÁ, M. MATÚŠKOVÁ*
}

\begin{abstract}
Laboratory of Molecular Oncology, Cancer Research Institute of Slovak Academy of Sciences, Vlárska 7, 83391 Bratislava, Slovak Republic
\end{abstract}

Received March 15, 2013; accepted January 24, 2014

\begin{abstract}
Summary. - Mesenchymal stem/stromal cells (MSC) possess a set of several fairly unique properties which make them ideally suitable both for cellular therapies and regenerative medicine. These include: relative ease of isolation, the ability to differentiate along mesenchymal and non-mesenchymal lineages in vitro and the ability to be extensively expanded in culture without a loss of differentiative capacity. MSC are not only hypoimmunogenic, but they mediate immunosuppression upon transplantation, and possess pronounced anti-inflammatory properties. They are able to home to damaged tissues, tumors, and metastases following systemic administration. The ability of homing holds big promise for tumor-targeted delivery of therapeutic agents. Viruses are naturally evolved vehicles efficiently transferring their genes into host cells. This ability made them suitable for engineering vector systems for the delivery of genes of interest. MSC can be retrovirally transduced with genes encoding prodrug-converting genes (suicide genes), which are not toxic per se, but catalyze the formation of highly toxic metabolites following the application of a nontoxic prodrug. The homing ability of MSC holds advantages compared to virus vehicles which display many shortcomings in effective delivery of the therapeutic agents. Gene therapies mediated by viruses are limited by their restricted ability to track cancer cells infiltrating into the surrounding tissue, and by their low migratory capacity towards tumor. Thus combination of cellular therapy and gene delivery is an attractive option - it protects the vector from immune surveillance, and supports targeted delivery of a therapeutic gene/protein to the tumor site.
\end{abstract}

Keywords: mesenchymal stromal cells; retroviral vectors; cancer gene therapy; prodrug-converting genes

\section{Contents:}

1. Main characteristics of mesenchymal stromal/stem cells

2. MSC as suitable vehicles for gene therapy

3. Retroviral vectors for gene therapy

*Corresponding author: E-mail: miroslava.matuskova@savba.sk; phone: +421-2-593-27418.

Abbreviations: 5-FC = 5-fluorocytosine; 5-FU = 5-fluorouracil; AT-MSC = adipose tissue-derived mesenchymal stromal/stem cells; $\mathrm{CD}=$ cytosine deaminase; $\mathrm{CD}:: \mathrm{UPRT}-\mathrm{MSC}=\mathrm{MSC}$ expressing $\mathrm{cy}-$ tosine deaminase::uracil phosphoribosyl transferase; $\mathrm{GCV}=$ ganciclovir; GCV-TP = ganciclovir triphosphate; GDEPT = gene directed enzyme prodrug therapy; HSVtk = Herpes simplex virus thymidine kinase; MLV = murine leukemia virus; MSC = mesenchymal stromal cells/mesenchymal stem cells; PNP = purine nucleoside phosphorylase; RCRV = replication competent retroviral vector; UPRT $=$ uracil phosphoribosyl transferase
4. Genetically engineered MSC for gene directed enzyme prodrug therapy

5. Herpes simplex virus thymidine kinase/ganciclovir approach

6. Cytosine deaminase/5-fluorocytosine approach

7. Purine nucleoside phosphorylase/fludarabine approach

8. Conclusions

\section{Main characteristics of mesenchymal stromal/ stem cells}

Population of rare, non-hematopoietic progenitor cells was originally isolated from bone marrow based on their ability to adhere to plastic culture dishes. Friedenstein et al. (1970) found them to be clonogenic in culture and multipotent for stromal precursors. Years later, scientists began to 
explore the full potential of these cells, and they discovered that this population had properties of true stem cells (Caplan, 1991). A stem cell has the capacity for self-renewal and the ability to give rise to one or more types of differentiated progeny (Prockop, 1997; Morrison et al., 1997). Within that context and based on its in vitro behavior, it seems that MSC might be qualified as stem cells thanks to their vast proliferative potential, clonal regeneration and production of differentiated cells (Pittenger et al., 1999).

Extensive research revealed that cells obtained from bone marrow, adipose tissue, umbilical cord or other sources by plastic adherence are composed of heterogenic population of progenitor cells in various state of development, out of which "true stem cells" form only a subpopulation. We prefer designation "stromal", however we would like to respect the opinion of other researchers cited in this review, therefore we use both terms as they occur in literature. The abbreviation "MSC" is used for both "stem" and "stromal" cells and means population of adherent progenitor cells with defined panel of surface markers and ability to differentiate under specific culture conditions.

MSC are currently defined by a combination of phenotypic, morphologic, physical and functional properties (Javazon et al., 2004). The classical methodology identifies MSC by the colony forming unit (CFU) assay, which recognizes adherent spindle-shaped cells proliferating to form colonies, and which are able to differentiate into adipocytes, osteocytes and chondrocytes in vitro (Galderisi et al., 2010).

The ISCT (The International Society for Cellular Therapy) has provided the minimum criteria for defining these multipotent cells. As stated above they adhere to plastic under standard culture conditions; differentiate to adipogenic, chondrogenic, and osteogenic lineages; express CD73, CD90, CD105, and do not express CD45, CD34, CD14 or CD11b, CD79 $\alpha$ or CD19 and HLA-DR (Dominici et al., 2006). In addition to standard methods of cell characterization, the relative benefits of more advanced molecular tools including assessments of the cell transcriptome, proteome, and secretome should be evaluated in creating new definition (Keating, 2012; Ranganath, 2012).

Because MSC populations are heterogeneous between species and within cultures, variable expression of surface markers is often observed. These discrepancies arise due to differences in isolation method, tissue and species of origin, and culture conditions (Javazon et al., 2004). MSC have the ability to give rise not only to cells of mesenchymal origin, but to cells of all three germinal layers, which means that they have the ability to cross developmental boundaries (Porada and Almeida-Porada, 2010). It is assumed that the differentiation toward a particular tissue lineage is primarily driven by the tissue-specific microenvironment (Breitbach et al., 2007).

No expression of costimulatory molecules makes them regarded as non-immunogenic and suggests that these cells might be effective in inducing tolerance. MHC class I may activate alloreactive $\mathrm{T}$ cells, but a secondary signal would not engage with the absence of costimulatory molecules, leaving T cells anergic (Tse et al., 2003; Le Blanc et al., 2003; Kidd et al., 2008). Recent studies have provided evidence that MSC are not only relatively non-immunogenic, but they also appear to have immunosuppressive and anti-inflammatory properties both in vitro and in vivo (Porada and AlmeidaPorada, 2010). It has also been shown that MSC impair maturation and function of dendritic cells and inhibit human $\mathrm{B}$ cell proliferation, differentiation, and chemotaxis in vitro (Aggarwal and Pittenger, 2005). Due to their suppression of the lymphocyte proliferative response to allogeneic and xenogenic antigens (Le Blanc et al., 2003), transplantation into an allogeneic host may not require immunosuppression (Javazon et al., 2004).

\section{MSC as suitable vehicles for gene therapy}

The poor prognosis for patients with aggressive or metastatic tumors and the toxic side effects of currently available treatments necessitate the development of more effective tumor-selective therapies. Thanks to tumor-tropic properties, stem cells can be exploited for targeted delivery of anticancer genes (Aboody et al., 2008). The ideal candidates of cellular therapy for clinical use are cells harvested without difficulty, which can be processed ex vivo very efficiently, and afterwards transplanted. MSC possess all these properties and thus could be suitable for use in human clinical trials (Giordano et al., 2007b).

Despite significant advances in the field of cancer gene therapy, two major obstacles which limit the clinical potential of this approach remain: lack of tumor tropism of vectors and stimulation of immune response. Thus combination of cellular therapy and gene delivery is an attractive option - it would protect the vector from immune surveillance, and support targeted delivery of a gene or therapeutic protein to the tumor site (Dwyer et al., 2010).

In addition to differentiative, trophic, and immunomodulatory properties, a large number of preclinical animal studies also highlighted another interesting and clinically valuable characteristic of MSC - their ability to selectively navigate to sites of injury or inflammation within the body (Jiang et al., 2006). Tumors and their surroundings can be considered as "wounds that never heal" (Dvorak, 1986) and contain high numbers of inflammatory cells and cytokines that attract MSC (Dwyer et al., 2007). The mechanism, by which MSC home to tissues and migrate across endothelium, is not yet fully understood, but it is likely that injured tissue expresses specific receptors or ligands to facilitate trafficking, adhesion, and infiltration of MSC, as in the case of recruitment of leukocytes to sites of inflammation (Chamberlain et al., 2007). 
It means that integration into the tumor stroma is thought to be mediated by high local concentrations of inflammatory chemokines and growth factors, such as epidermal growth factor-A, fibroblast growth factor, platelet-derived growth factor, stromal-derived growth factor $1 \alpha$ (SDF-1a/CXCL12), IL-8, IL-6, granulocyte-macrophage colony-stimulating factor, etc. (Kucerova et al., 2010; Dwyer et al., 2010). On the other hand, MSC have been reported to express a number of adhesion molecules including integrins, CD44, CD54/ ICAM-1, CD106/VCAM-1, CD166/ALCAM (Minguell et al., 2001). The functional chemokine receptors on MSC include CCR1, CCR7, CCR9, CXCR3, CXCR4, CXCR5, CX3CR1, and c-met (Myers et al., 2010; Dwyer et al., 2010). Variability of receptors reflects the heterogeneity of cultured MSC. This expression variability suggests that they show the potential to home to different tissues (Chamberlain et al., 2007). MSC possess the ability to migrate to tumor foci regardless of tumor size, anatomic location or tissue of origin (Najbauer et al., 2007). The unique ability to cross the blood-brain barrier provides a very attractive advantage in treating central nervous system-associated tumors (Aboody et al., 2006; Danks et al., 2007).

The issue of spontaneous transformation of MSC is a matter of debate (Lazennec and Jorgensen, 2008). The risk of tumorigenicity is far lower in cells from adult tissues but increases if cells are expanded in culture. Many cells display a limited lifespan in culture and progress to senescence. However, attention must be paid to the culture conditions (Prockop et al., 2010). It has been shown, by using genomic hybridization, karyotyping, subtelomeric fluorescent in situ hybridization and telomerase activity, that human bone marrow-derived MSC (BM-MSC) do not undergo transformation in long-term culture under appropriate conditions and also do not express telomerase or exhibit telomere shortening (Bernardo et al., 2007). Tumorigenicity of adult MSC has never been proven. Some studies demonstrated that MSC can undergo malignant transformation in vivo. However, investigators have now found that "malignant" MSC were contaminated with fibrosarcoma and/or osteosarcoma-derived cells (Klopp et al., 2011). In order to evaluate if retroviral transduction and subsequent antibiotic selection change the properties of MSC or select rapidly proliferating subpopulations, we compared naive MSC with genetically engineered populations. We did not observe a general increase in MSC proliferation or chemosensitivity which could be attributed to retroviral transduction itself. Increased proliferation of CD::UPRT-MSC (MSC expressing yeast cytosine deaminase fused with uracil phosphoribosyl transferase) was caused by the expression of enzymes involved in nucleotide metabolism. This proliferation advantage was lost in highpassage cultures. No substantial difference was observed in number of senescent cells between untransduced (naive) and retrovirally transduced cells (Kucerova et al., 2012). It appears that murine MSC are more susceptible to chromosomal aberration under in vitro cultivation than human cells (Tolar et al., 2007).

MSC were shown to efficiently home to sites of injury and actively participate in tissue repair by secreting cytokines and growth factors that can restore tissue homeostasis, by reducing local inflammation and by differentiating in one or more cell types resident in the injured tissue (Spees et al., 2003; Keating, 2006). There has been done a great deal of work, some of which is quite promising and can be therapeutically useful in repair of skeletal tissues, myocardia, CNS or spinal injury (Javazon et al., 2004; Myers et al., 2010). MSC are currently being investigated in clinical trials for a wide spectrum of indications, ranging from cell replacement to immunotherapy (Giordano et al., 2007a; Ringden et al., 2006).

Tumor-favoring potential of MSC is also a hot research topic. These cells are known to support tumor angiogenesis and metastasis formation, to create a microenvironment favorable for growth of cancer cells and to down-modulate the immune system capabilities in the host organism (Galderisi et al., 2010). Both protumorigenic and antitumorigenic effect of AT-MSC has been demonstrated on malignant cell behavior dependent on the mutual interplay between stromal and malignant cells (Kucerova et al., 2010, 2011a).

\section{Retroviral vectors for gene therapy}

Viruses have been selected as gene delivery vehicles because of their capability to deliver foreign genes efficiently, and sustain their expression. They have evolved mechanisms to enter the cells and use the cellular machinery to express their genes ( $\mathrm{Hu}$ and Pathak, 2000). These are the major reasons why viral vectors derived from retroviruses, adenoviruses, adeno-associated viruses, herpesviruses and poxviruses are employed in many clinical gene therapy trials worldwide. Among these systems, retroviral vectors represent the prominent delivery system, since these vectors have high gene transfer efficiency and mediate high expression of genes. The advantages are also determined by their stable integration into the host genome, generation of viral titres sufficient for efficient gene transfer, infectivity of the recombinant viral particles for a broad variety of target cell types and ability to carry foreign genes of sizes $<8 \mathrm{~kb}$. These properties are essential prerequisite for persistence of the transgene in transduced cells and their progeny (Walther and Stein, 2000).

The retroviral vectors are predominantly derived from the moloney murine leukemia virus (MLV). The amphotropic virus is able to infect murine cells and variety of other cell species including human cells (Battini et al., 1992).

Retroviruses were the first viruses to be modified for gene delivery (Anderson, 1996). An ideal vector must be efficient, 
cell-specific, regulated, and safe (Hu and Pathak, 2000). The location of most cis-acting sequences in the terminal regions has enabled simple and effective retrovector design, making them the most widely used vector system (Rosenberg et al., 2000). The host transcription machinery recognizes these cis-acting elements and thus mediates expression of the viral genes (Chang and Yee, 2012).

For most gene therapy applications, it is not desirable to deliver a replication-competent virus into a patient because of possible spreading beyond the target tissue and possibility of adverse effects. Therefore, the viral components are divided into a vector and a helper construct to limit the ability of the virus to replicate freely (Miller, 1997). It is necessary to separate genes encoding for structural and enzymatic proteins $(\mathrm{Gag} / \mathrm{Pol})$, as well as the genes encoding envelope proteins (Env) from the retroviral genome, which can be achieved by the so-called split packaging design. The retroviral vector contains the packaging signal $(\Psi)$, the primer binding site (PBS), the long terminal repeats (LTR), and harbors the transgene of interest (Maetzig et al., 2011) (Fig. 1). Helper constructs are designed to express viral genes that are missing in the vectors and to support replication of the vectors. The helper function is most often provided in a helper cell format. When the viral particles infect target cells, the vector RNA is reverse transcribed to form a double-stranded DNA copy, which integrates into the host genome and forms a provirus encoding the gene(s) of interest. It is further expressed by the host cell machinery. However, because the vector does not express any viral proteins, it cannot produce infectious viral particles which could spread to other cells ( $\mathrm{Hu}$ and Pathak, 2000). The removal of the structural genes does not interfere with the capability of the viral RNA to be packaged into infectious retroviral particles (Walther and Stein, 2000). Furthermore, the removal of the structural genes from the viral vector and of the packaging signal from the packaging vector constructs gives the basis for safe and efficient production of recombinant virus particles for infection of the target cells (Markovitz et al., 1988). Introduction of the transgene containing construct into a packaging cell line via transfection allows the establishment of stable producer cell lines for viral vector production. Since MLV infection does not cause any obvious pathogenic effect on cells, these producer cell lines continue to proliferate and secrete infectious virions into the culture media (Sheridan et al., 2000).

The useful property of retroviral vectors is their ability to integrate efficiently into the chromatin of target cells. Although integration does not guarantee stable expression of the transduced gene, it is an effective way to maintain the genetic information in a proliferating or self-renewing tissue (Roe et al., 1993). Gammaretroviral vectors are dependent on degeneration of the nuclear membrane during cell division to allow the virus to enter the nucleus. Lentiviral vectors actively enter the nucleus via the nuclear pore, thus enabling them to transduce non-dividing cells. Despite many years of investigation, precise mechanisms of target site selection and the interplay of viral integrase and host cell proteins are still unknown. Gammaretroviral vectors show a strong preference for integration close to transcription start sites (TSS) and CpG islands, which are enriched in gene regulatory elements. On the other hand, lentiviral vectors prefer integration inside of the transcription units of actively transcribed genes (Gabriol et al., 2012).

The relative concentration of vectors is evaluated as a titer expressed as the concentration of viral particles and/or the number of virions that are capable of transduction. The producing particles usually represent only a small percentage of total particles (Kay et al., 2001). The assay for vector titer and selection of transduced cells depend on the marker in the vector. The most popular used include the gene encoding fluorescence proteins like GFP or antibiotics selectable mark-

(a)

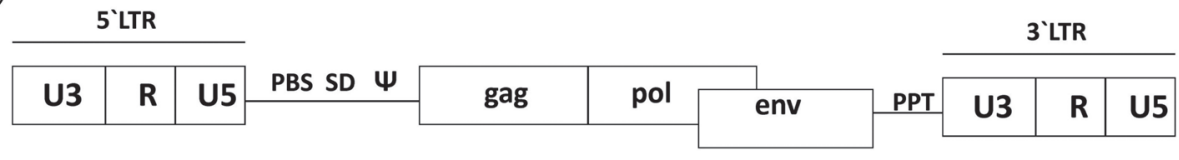

(b)

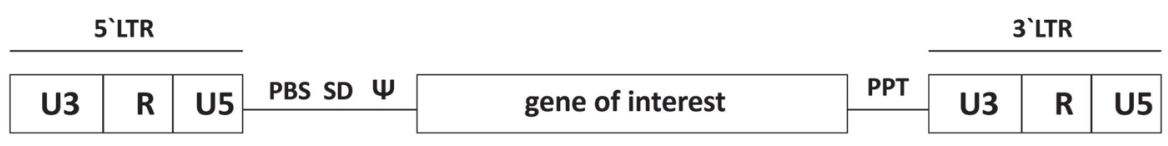

Fig. 1

Comparison of the genome structure of integrated retrovirus and retroviral vector

(a) Diagram of MLV provirus; (b) Diagram of integrated MLV-derived retroviral vector; LTR = long terminal repeat; U3 = unique sequence derived from 3' end of the viral RNA; R = repeated sequence; U5 = unique sequence derived from 5' end of the viral RNA; PBS = primer binding site; SD splice donor; $\Psi$ = packaging signal; gag = genes for structural proteins; pol = region coding for genes needed for replication of retrovirus; env = genes for envelope proteins; PPT = polypurine tract (according to Maetzig et al., 2011, adjusted). 
ers like neo ${ }^{\mathrm{R}}$ gene. Antibiotics selection takes approximately 2 weeks with repeated medium changes. This selection can detect even a few transduced cells in a population of $10^{6}$ untransduced cells (Chang and Yee, 2012).

Therapeutic viruses based on retroviral vectors generated by packaging cell lines are often used in different gene therapy approaches. Low transduction efficiency and low titer represent the main disadvantages for their usage. This issue can be solved by generation of highly retrovirus-producing cells. So-called "ping-pong amplification" between ecotropic and amphotropic packaging cell lines (with different host range) was found to be effective for an increase of virus production (Hlavaty et al., 1999).

In self-inactivating vectors (SIN), the promoter/enhancer sequences within the U3 region of the viral 3 ' -LTR are deleted or mutated to prevent insertional activation of genes in the host genome for the safety of retroviral vector. After viral reverse transcription, both the 3 '-LTR and 5 '-LTR are transcriptionally inactive, without any interference with expression of the internally promoted therapeutic genes ( $\mathrm{Yu}$ et al., 1986).

To increase in vivo transduction efficiency, a new generation of replication-competent or conditionally replicative viral vectors have been successfully analyzed for their natural or genetically enhanced oncolytic potential (Wollmann et al., 2005). Replication competent retroviral vectors (RCRV) were created to deliver the therapeutic gene to almost all tumor cells (Dalba et al., 2007; Tai and Kasahara, 2008). RCRV based on MLV exhibit unique characteristics thanks to MLV intrinsic tumor selectivity due to its inability to infect quiescent cells. It can also achieve highly selective and stable gene transfer throughout entire solid tumors in vivo. RCRV with suicide gene mediate synchronized cell killing after prodrug administration, and due to their ability to undergo stable integration, residual cancer cells serve as a reservoir for long-term viral persistence even when they migrate to new sites. This enables multiple cycles of prodrug administration to achieve improved treatment efficacy (Tai and Kasahara, 2008). While neutralizing antibody responses to MLV do occur, it has been shown that it causes only minor inflammation, with little effect on viral titer, and no associated pathology (Ram et al., 1993; Hein et al., 1995). Very promising results using RCRV were achieved by Hlavaty et al. (2011) by injection of the vector into the orthotopic mouse tumor xenografts revealing substantial infection and virus spread. Significant bystander effect was observed in all human glioma cell lines tested.

\section{Genetically engineered MSC for gene directed enzyme prodrug therapy}

Many (pre)clinical studies targeting of solid tumors with anti-cancer gene therapy has been hindered by systemic toxicity, low efficiency of delivery and transient expression of transgene. Cell-based targeting using MSC has been utilized to overcome these issues. The tumor-specific migratory ability makes MSC possible for delivery of toxic substances to the main tumor mass and its surrounding niche, as well as to invasive parts, without adverse effects on normal tissue (Bexell et al., 2010; Myers et al., 2010). Tumor-homing capability of MSC was demonstrated on many models. They are able to migrate to primary or metastatic tumors derived from glioma, breast, colon, ovarian, lung or prostatic carcinoma or melanoma upon systemic administration (Kucerova et al., 2007, 2008; Cavarretta et al,. 2010; Reagan and Kaplan, 2011).

One of the cancer gene therapy approaches involves delivery and expression of prodrug-converting genes (suicide genes), which encode enzymes not toxic per se, but catalyzing the formation of highly toxic metabolites following the application of a much less toxic prodrug. The use of suicide gene/prodrug combinations is known as gene directed enzyme prodrug therapy (GDEPT). GDEPT describes a process whereby the expression of exogenous genetic information generates a product which increases the toxicity of an administered prodrug. There is a set of properties that the "perfect" suicide gene/prodrug combination should exhibit, but ideal combination of properties still does not exist. The suicide gene/gene product should be either absent in the human genome, or expressed at low levels, and should not be toxic; it should exhibit high catalytic activity upon expression in tumors; be sufficient for full activation of the prodrug without the necessity for further catalysis by endogenous enzymes; and it should be small - allowing the use of expression vectors. The prodrug should have high affinity for the enzyme encoded by the suicide gene; should be able to penetrate into a solid tumor and be efficiently taken up by tumor cells; have a half-life long enough to maximize the bystander effect within the tumor; exhibit no toxicity prior to activation; the toxic form(s) of the drug should be able to diffuse intercellularly - to allow killing of tumor cells via the bystander effect; the toxicity of the activated prodrug should be cell cycle-phase independent (Portsmouth et al., 2007).

Therapeutic genes that have been inserted into stem cells and delivered to tumors with high selectivity include prodrug activating enzymes (cytosine deaminase, thymidine kinase, carboxyl esterase); interleukins (IL-2, IL-4, IL-12, IL-23); interferon $\beta$; apoptosis-promoting genes (tumor necrosis factor-related apoptosis-inducing ligand, TRAIL); metalloproteinases (PEX); chemokine (CX3CL1) or antagonist of hepatocyte growth factor (NK4) (Aboody et al., 2008; Menon et al., 2009).

Cancer gene therapy using suicide genes is limited by the impossibility to introduce the gene into all cells of the tumor mass. Therefore, the presence of so-called bystander effect provides an advantage in this type of treatment. Therapeu- 
tic MSC release toxic metabolites that affect surrounding tumor cells (Hlavaty et al., 1997) (Fig. 2). Numerous studies performed with suicide gene/prodrug combinations have demonstrated that complete tumor eradication is possible even when the suicide gene is expressed by less than $10 \%$ of cells (Cihova et al., 2011; Kucerova et al., 2013). Bystander effect can either be exerted by the free/facilitated diffusion of toxic metabolites or thanks to intercellular communication via gap junctions. It can be further improved by the immune system, whereby the release of foreign and/or tumor antigens from dying cells stimulate the immune system to eliminate tumor cells which do not express the suicide gene (Portsmouth et al., 2007).

In order to address the safety of retrovirally transduced MSC many studies have been performed. Piccoli et al. (2008) demonstrated increased reactive oxygen species production in engineered BM-MSC due to regularly used selection markers. Expression of neomycin or puromycin resistance genes resulted in oxidative stress. As stated above, particular transgene can give a proliferative advantage but it does not preclude the entering of cells to senescence, and has no impact on safety of cancer gene therapy mediated by mesenchymal stromal cells (Kucerova et al., 2012).

\section{Herpes simplex virus thymidine kinase/ganciclovir approach}

One of the most frequently studied therapeutic strategies is based on transfection with the Herpes simplex virus thymidine kinase gene (HSVtk) followed by ganciclovir (GCV) administration (Dillen et al., 2002). One of about 70 proteins encoded by HSV-1, the 376 amino acid containing protein product of the HSVtk gene is needed by the virus for reactivation from ganglionic neurons during the latent stage of its life-cycle, since these cells express very low levels of endogenous thymidine kinase. The enzyme initiates the phosphorylation of deoxythymidine to deoxythymidine triphosphate for incorporation into nascent DNA. Expression of HSVtk to activate the acyclovir-derived prodrug 9-([2-hydroxy-1-(hydroxymethyl)ethoxy]methyl) guanine - ganciclovir was used for the first proof-of-principle of suicide gene therapy by Moolten in 1986. HSVtk is 1000fold more efficient in monophosphorylating ganciclovir in comparison to mammalian thymidine kinases (Portsmouth et al., 2007). The final product of consequent phosphorylation by cellular kinases, GCV-triphosphate (GCV-TP), competitively inhibits incorporation of the endogenous

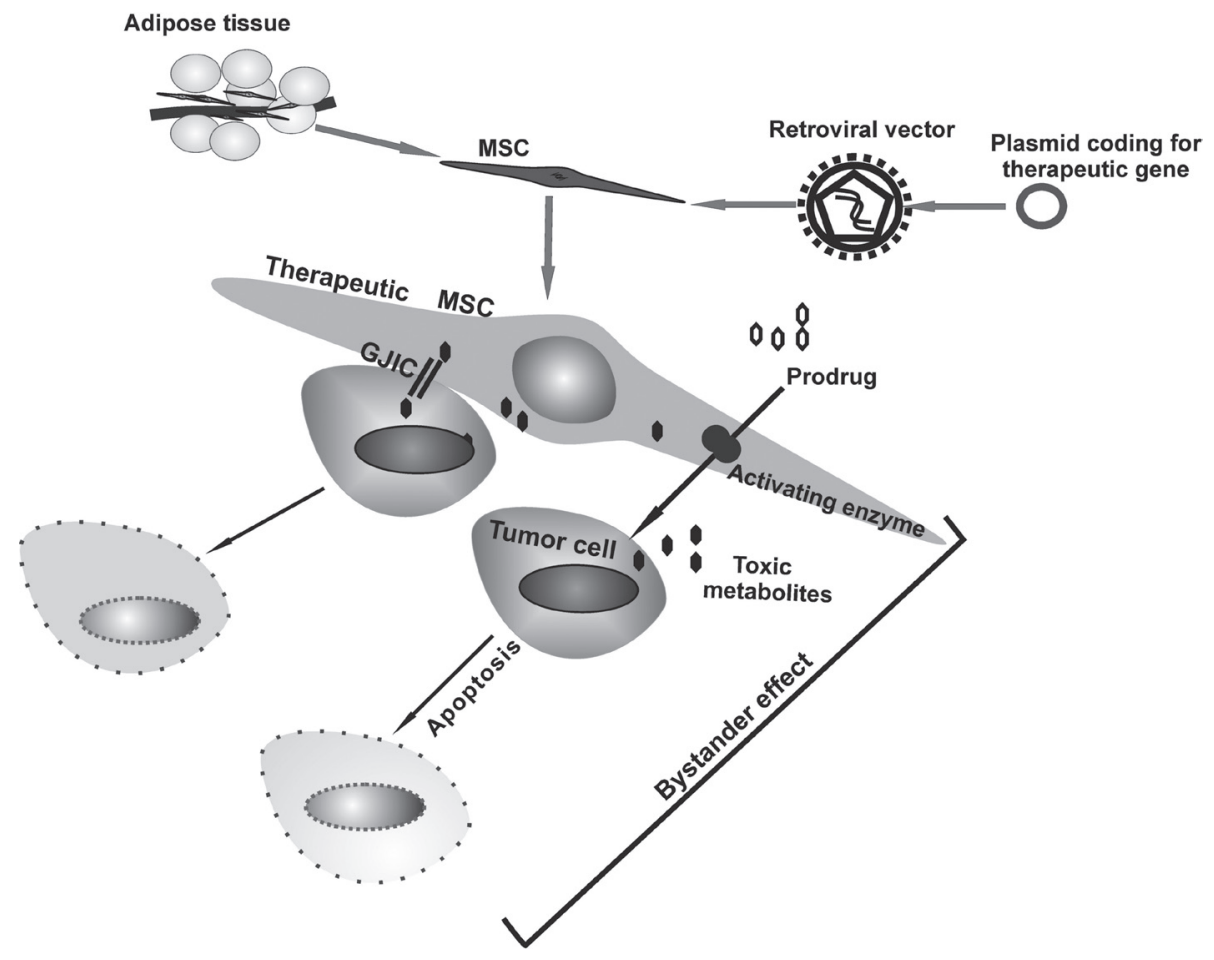

Fig. 2

GDEPT mediated by AT-MSC is based on bystander effect

AT-MSC are expanded and retrovirally transduced by prodrug-converting genes in order to express enzymes converting nontoxic prodrug to toxic metabolites. Engineered MSC release toxic metabolites by diffusion or via gap junctions. Uptake of toxic compounds by surrounding tumor cells induces apoptosis. 
DNA precursor deoxyguanosine triphosphate (dGTP) into DNA. The GCV-terminated strands of DNA are poor substrates for chain elongation, therefore the elongation of DNA is canceled and leads to cell death. Thus, replicating DNA is considered to be the major target in cancer cells for GCV activated by HSVtk (Mesnil and Yamasaki, 2000). It has also been indicated that GCV induced a morphological change in cells due to the reorganization of the cytoskeleton as well as an accumulation of cells in G2/M phase of cell cycle after 48-72 hr incubation (Halloran and Fenton, 1998). It has also been reported that treatment resulted in a Bcl-2 levels decline and activation of caspases, leading to apoptosis (Tomicic et al., 2002). It has been demonstrated that GCV induced sister chromatid exchanges, chromosome breaks and translocations, suggesting an involvement of the homologous recombination repair in responding to GCV-induced DNA damage (Thust et al., 2000a,b). It was suggested that phosphorylated GCV in the template blocked successful repair by homologous recombination, leading to cell death. These findings indicate that combining HSVtk/ GCV with approaches that compromise homologous recombination repair could produce synergistic antitumor effects (Ladd et al., 2011).

The cytotoxic GCV-TP is charged and therefore insoluble in lipid membranes, it cannot diffuse into neighboring cells and exert its toxic effects. However, a bystander effect is observed in vitro and in vivo when using this system. This is due to transfer of GCV-TP across gap junctions (GJs) which are formed between opposing plasma membranes. Gap junctions are composed of connexons (two juxtaposed transmembrane hemichannels consisting of six connexin (Cx) protein subunits). These intercellular channels with a central pore permit the transfer of molecules with less than Mr 1000 directly from one cell to another (Dillen et al., 2002; Mesnil and Yamasaki, 2000).

It has been proposed that the bystander effect can be facilitated by apoptotic vesicles containing GCV-TP released from dying cells, which are phagocytosed by nonHSVtk-expressing cells (Freeman et al., 1993). It was also hypothesized that gap junctional intercellular communication (GJIC) can protect the transduced cell by lowering its concentration of cytotoxic metabolites. This protection could permit the transduced "factory" to live longer, which could then kill more bystander cells, and has been called "Good Samaritan" effect (Wygoda et al., 1997).

It was evaluated whether human AT-MSC could be exploited as cellular vehicles for HSVtk/GCV enzyme/prodrug combination to mediate cytotoxic effect on human tumor cells. Adipose-tissue derived human mesenchymal stromal cells were shown to form gap junctions with glioblastoma cells, thus rendering them suitable vehicle for the HSVtk/GCV therapy relying on transport of polar metabolites (Matuskova et al., 2010).

\section{Cytosine deaminase/5-fluorocytosine approach}

The second extensively studied prodrug/converting gene system represents cytosine deaminase (CD) and 5-fluorocytosine (5-FC). This enzyme is present in fungi and bacteria but is absent in mammalian cells. It deaminates cytosine to uracil, and can also deaminate the nontoxic prodrug 5 -fluorocytosine to its highly toxic derivative 5-fluorouracil (5-FU). This metabolite is then converted by cellular enzymes into 5-FUTP (5-fluorouridine triphosphate) and 5-FdUMP (5-fluorodeoxyuridine monophosphate). 5-FUTP can be incorporated into RNA in place of UTP, resulting in the inhibition of the nuclear processing of the ribosomal and messenger RNA. 5-FdUMP irreversibly inhibits thymidylate synthase, a key enzyme in the de novo synthesis of dTMP, a precursor for DNA synthesis (Altaner, 2008; Scartozzi et al., 2011). 5-FU is a chemotherapeutic agent widely used for the treatment of several solid tumors. Many years after its first introduction, it still represents the backbone of many chemotherapy combinations (Scartozzi et al., 2011). However, certain cancer cells may become relatively resistant to 5-FU because of its poorly efficient conversion to toxic metabolites (Harris et al., 1994). Escherichia coli and Saccharomyces cerevisiae encode genes $u p p$ and FUR1. Their product is an enzyme called UPRT (uracil phosphoribosyl transferase) that can actively convert uracil to uridine monophosphate (UMP). Transfer of these genes to cells in GDEPT should induce a more efficient conversion of 5-FU to 5-fluorouridine monophosphate (5-FUMP), thus restoring the sensitivity of cells to 5-FU (Erbs et al., 2000).

As in contrast to GCV-P derivatives, 5-FC and 5-FU can penetrate tumor cells by diffusion and exert the local toxic effect on neighboring cells, regardless of the presence of GJIC, which means that direct cell-to-cell contact is not necessary (Altaner, 2008). 5-FC is able to cross the blood-brain barrier, making this enzyme/prodrug approach well suited for the treatment of CNS tumors (Aboody et al., 2008; Altaner and Altanerova, 2012; Cihova et al., 2011).

Yeast cytosine deaminase was shown to produce a 15-fold higher amount of 5-FU compared to bacterial CD (Kievit et al., 2000). The improvement in the efficiency of prodrug conversion was achieved by construction of bifunctional yeast fusion gene cytosine deaminase::uracil phosphoribosyl transferase (CD::UPRT). The gene product of a chimeric protein catalyzes the direct conversion of 5-FC into 5-FUMP and its enzymatic activity is increased at least 100 -fold over native yeast CD. CD::UPRT as a prodrug-converting enzyme was reported to exhibit improved 5-FC conversion efficiency and higher bystander effect in vitro and in vivo (Graepler et al., 2005; Altaner, 2008). This therapeutic regimen has proven efficacious in the treatment of experimental human colon carcinoma (Kucerova et al., 2007), prostate tumor (Cavarretta et al., 2010), melanoma (Kucerova et al., 2008) and 
medullary thyroid carcinoma (Kucerova et al., 2011b). Many studies were performed on glioblastoma model (Altaner and Altanerova, 2012). Coadministration of rat glioblastoma and therapeutic mesenchymal stem cells with delayed 5-FC therapy improved the survival in a therapeutic stem cell dose-dependent manner, and induced tumor regression in a significant number of animals (Altanerova et al., 2012). CD::UPRT-MSC were also capable of mediating increased cytotoxic effect of 5-FU on EGFP-MDA-MB-231 breast cancer cells. The bystander cytotoxicity of CD::UPRT/5FU treatment was much more efficient when compared to treatment with 5-FU alone or CD::UPRT/5-FC (Kucerova et al., 2012). We have demonstrated that particular tumor cell lines differ in response to CD::UPRT-MSC/5-FC system. Pharmacological inhibition of enzymes involved in the metabolism of 5-FC and 5-FU led to decreased sensitivity to treatment. Molecular inhibition of ABCC11 (MRP8) by RNA interference abrogated resistance to CD::UPRT-MSC/5-FC treatment caused by efflux of 5-FC metabolites (Matuskova et al., 2012). Cihova et al. (2011) found that the high efficacy of CD::UPRT-MSC is caused by paracrine induction of proapoptotic genes in tumor cells. Significant increase of products of proapoptotic genes Bad, Bax, TRAIL R1/DR4, and FADD was detected in colorectal carcinoma cells. On the other hand, the amount of products of antiapoptotic genes $\mathrm{Bcl}-2$ and Bcl-X was decreased.

\section{Purine nucleoside phosphorylase/fludarabine approach}

Purine nucleoside phosphorylase (PNP) catalyzes the cleavage of the glycosidic bond of purine nucleosides to generate ribose 1-phosphate and a free purine base (Zhang et al., 2005). Although this reversible phosphorolysis of ( $2^{\prime}$-deoxy) purine ribonucleosides is a shared property of prokaryotic and eukaryotic PNP, the mammalian enzymes differ in sequence, structure, and function from their bacterial counterparts. An important difference between E.coli and mammalian enzyme is the ability of E. coli PNP to cleave adenosine analogs, thus its expression in cancer cells mediates the glycosidic cleavage of nucleoside prodrugs to highly toxic adenine analogs. This enzyme is being evaluated by numerous laboratories as a suicide gene therapy strategy for the treatment of solid tumors. The compounds based on three 2'-deoxyadenosine analogues: 6-methylpurine2'-deoxyriboside (MePdR), 2'- Deoxy- 2'- fluoroadenosine (2'-F-dAdo), and 9-( $\beta$-d-arabinofuranosyl)-2-fluoroadenine (F-araA) with excellent in vitro and in vivo activity diffuse across cell membranes and effectively kill transduced cells as well as the adjacent tumor cells that do not express E. coli PNP. Gap junctions or cell-to-cell contacts are not required to transport analogues across cell membranes. Excellent by- stander activity has also been demonstrated in vivo (Zhang et al., 2005; Hong et al., 2004). According to Hong et al. (2004), this therapeutic approach is capable of destroying the quiescent (non-cycling) compartment of tumor cells in vivo. Mice given PNP-GDEPT showed a significant reduction both in prostate volume and in lung colony counts. Apoptosis was increased two-fold in treated prostates compared to controls (Martiniello-Wilks et al., 2004). Thus preclinical studies using animal models have demonstrated that PNP anticancer gene therapy is a promising approach for the treatment of solid tumors.

\section{Conclusions}

Mesenchymal stromal cells retrovirally transduced to express therapeutic genes thanks to their ability to preferentially migrate toward tumor cells seem to be attractive candidates for clinical applications of stem cell-mediated cancer gene therapy. These engineered MSC have the "suicide" concept included within, therefore are safe for the therapeutic use regarding their indicated tumor-favoring properties.

Acknowledgements. We thank Marina Cihova for reading the manuscript. The studies and experiments mentioned in this review were performed with the kind support provided by the RFL and WAC programs funded by the Slovak Cancer Research Foundation, the League against Cancer, VEGA grants No. 2/0146/10 and 2/0088/11, APVV grants No. APVV-0260-07 and APVV-0230-11.

\section{References}

Aboody KS, Bush RA, Garcia E, Metz MZ, Najbauer J, Justus KA, Phelps DA, Remack JS, Yoon KJ, Gillespie S, Kim SU, Glackin CA, Potter PM, Danks MK, PLoS One 1, e23, 2006. http://dx.doi.org/10.1371/journal.pone.0000023

Aboody KS, Najbauer J, Danks MK, Gene Ther. 15, 739-752, 2008 http://dx.doi.org/10.1038/gt.2008.41

Aggarwal S, Pittenger MF, Blood 105, 1815-1822, 2005. http:// dx.doi.org/10.1182/blood-2004-04-1559

Altaner C, Cancer Lett. 270, 191-201, 2008. http://dx.doi. org/10.1016/j.canlet.2008.04.023

Altaner C, Altanerova V, Neoplasma 59, 756-760, 2012. http:// dx.doi.org/10.4149/neo 201295

Altanerova V, Cihova M, Babic M, Rychly B, Ondicova K, Mravec B, Altaner C, Int. J. Cancer 130, 2455-2463, 2012. http:// dx.doi.org/10.1002/ijc. 26278

Anderson WF, Hum. Gene Ther. 7, 2201-2202, 1996. http://dx.doi. org/10.1089/hum.1996.7.18-2201

Battini JL, Danos O, Heard JM, J. Virol. 66, 713-719, 1992.

Bernardo ME, Zaffaroni N, Novara F, Cometa AM, Avanzini MA, Moretta A, Montagna D, Maccario R, Villa R, Daidone MG, Zuffardi O, Locatelli F, Cancer Res. 67, 9142-9149, 2007. http://dx.doi.org/10.1158/0008-5472.CAN-06-4690 
Bexell D, Scheding S, Bengzon, Mol. Ther. 18, 1067-1075, 2010. http://dx.doi.org/10.1038/mt.2010.58

Breitbach M, Bostani T, Roell W, Xia Y, Dewald O, Nygren JM, Fries JW, Tiemann K, Bohlen H, Hescheler J, Welz A, Bloch W, Jacobsen SE, Fleischmann BK, Blood 110, 1362-1369, 2007. http://dx.doi.org/10.1182/blood2006-12-063412

Caplan AI, J. Orthop. Res. 9, 641-650, 1991. http://dx.doi. org/10.1002/jor. 1100090504

Cavarretta IT, Altanerova V, Matuskova M, Kucerova L, Culig Z, Altaner C, Mol. Ther. 18, 223-231, 2010. http://dx.doi. org/10.1038/mt.2009.237

Chamberlain G, Fox J, Ashton B, Middleton J, Stem Cells 25, 27392749, 2007. http://dx.doi.org/10.1634/stemcells.2007$\underline{0197}$

Chang T, Yee J-K, In Friedmann T (Eds): Methods in Enzymology. Vol. 507. Academic Press, New York-London, pp. 1-14, 2012.

Cihova M, Altanerova V, Altaner C, Mol. Pharm. 8, 1480-1487, 2011. http://dx.doi.org/10.1021/mp200151a

Dalba C, Bellier B, Kasahara N, Klatzmann D, Mol. Ther. 15, 457-466, 2007. http://dx.doi.org/10.1038/sj.mt.6300054

Danks MK, Yoon KJ, Bush RA, Remack JS, Wierdl M, Tsurkan L, Kim SU, Garcia E, Metz MZ, Najbauer J, Potter PM, Aboody KS, Cancer Res. 67, 22-25, 2007. http://dx.doi. org/10.1158/0008-5472.CAN-06-3607

Dillen IJ, Mulder NH, Vaalburg W, De Vries EF, Hospers GA, Curr. Gene Ther. 2, 307-322, 2002. http://dx.doi. org/10.2174/1566523023347733

Dominici M, Le Blanc K, Mueller I, Slaper-Cortenbach I, Marini F, Krause D, Deans R, Keating A, Prockop DJ, Horwitz E, Cytotherapy 8, 315-317, 2006. http://dx.doi. org/10.1080/14653240600855905

Dvorak HF, N. Engl. J. Med. 315, 1650-1659, 1986. http://dx.doi. org/10.1056/NEJM198612253152606

Dwyer RM, Khan S, Barry FP, O'Brien T, Kerin MJ, Stem Cell Res. Ther. 1, 1-7, 2010.

Dwyer RM, Potter-Beirne SM, Harrington KA, Lowery AJ, Hennessy E, Murphy JM, Barry FP, O'Brien T, Kerin MJ, Clin. Cancer Res. 13, 5020-5027, 2007. http://dx.doi. org/10.1158/1078-0432.CCR-07-0731

Erbs P, Regulier E, Kintz J, Leroy P, Poitevin Y, Exinger F, Jund R, Mehtali M, Cancer Res. 60, 3813-3822, 2000.

Freeman SM, Abboud CN, Whartenby KA, Packman CH, Koeplin DS, Moolten FL, Abraham GN, Cancer Res. 53, 5274-5283, 1993.

Friedenstein AJ, Chailakhjan RK, Lalykina KS, Cell Tissue Kinet. 3, 393-403, 1970.

Gabriol R, Schmidt M, van Kalle CH, Curr. Opin. Immunol. 24, 1-6, 2012. http://dx.doi.org/10.1016/j.coi.2012.01.004

Galderisi U, Giordano A, Paggi MG, World J. Stem Cells 2, 5-12, 2010.

Giordano A, Fucito A, Romano G, Marino IR, Front. Biosci. 12, 3475-3482, 2007a. http://dx.doi.org/10.2741/2328

Giordano A, Galderisi U, Marino IR, J. Cell. Physiol. 211, 27-35, 2007b. http://dx.doi.org/10.1002/jcp.20959

Graepler F, Lemken ML, Wybranietz WA, Schmidt U, Smirnow I, Gross CD, Spiegel M, Schenk A, Graf H, Lauer UA,
Vonthein R, Gregor M, Armeanu S, Bitzer M, Lauer UM, World J. Gastroenterol. 11, 6910-6919, 2005.

Halloran PJ, Fenton RG, Cancer Res. 58, 3855-3865, 1998.

Harris JD, Gutierrez AA, Hurst HC, Sikora K, Lemoine NR, Gene Ther. 1, 170-175, 1994.

Hein A, Czub S, Xiao LX, Schwender S, Dorries R, Czub M, Virology 211, 408-417, 1995. http://dx.doi.org/10.1006/ viro.1995.1423

Hlavaty J, Hlubinova K, Altaner C, Neoplasma 46, 267-276, 1999.

Hlavaty J, Hlubinova K, Altanerova V, Liska V, Altaner C, Neoplasma 44, 342-347, 1997.

Hlavaty J, Jandl G, Liszt M, Petznek H, König-Schuster M, Sedlak J, Egerbacher M, Weissenberger J, Salmons B, Günzburg WH, Renner M, J. Neurooncol. 102, 59-69, 2011. http:// dx.doi.org/10.1007/s11060-010-0295-5

Hong JS, Waud WR, Levasseur DN, Townes TM, Wen H, McPherson SA, Moore BA, Bebok Z, Allan PW, Secrist JA 3rd, Parker WB, Sorscher EJ, Cancer Res. 64, 6610-6615, 2004. http://dx.doi.org/10.1158/0008-5472.CAN-04-0012

Hu W-S, Pathak VK, Pharmacol. Rev. 52, 493-511, 2000.

Javazon EH, Beggs KJ, Flake AW, Exp. Hematol. 32, 414-425, 2004. http://dx.doi.org/10.1016/j.exphem.2004.02.004

Jiang W, Ma A, Wang T, Han K, Liu Y, Zhang Y, Dong A, Du Y, Huang X, Wang J, Lei X, Zheng X, Pflugers Arch. 453, 43-52, 2006. http://dx.doi.org/10.1007/s00424-006$\underline{0117-\mathrm{y}}$

Kay MA, Glorioso JC, Naldini L, Nat. Med. 7, 33-40, 2001. http:// dx.doi.org/10.1038/83324

Keating A, Curr. Opin. Hematol. 13, 419-425, 2006. http://dx.doi. org/10.1097/01.moh.0000245697.54887.6f

Keating A, Cell Stem Cell 10, 709-716, 2012. http://dx.doi. org/10.1016/j.stem.2012.05.015

Kidd S, Spaeth E, Klopp A, Andreeff M, Hall B, Marini FC, Cytotherapy 10, 657-667, 2008. http://dx.doi. org/10.1080/14653240802486517

Kievit E, Nyati MK, Ng E, Stegman LD, Parsels J, Ross BD, Rehemtulla A, Lawrence TS, Cancer Res. 60, 6649-6655, 2000.

Klopp AH, Gupta A, Spaeth E, Andreeff M, Marini F, Stem Cells 29, 11-19, 2011. http://dx.doi.org/10.1002/stem.559

Kucerova L, Altanerova V, Matuskova M, Tyciakova S, Altaner C, Cancer Res. 67, 6304-6313, 2007. http://dx.doi. org/10.1158/0008-5472.CAN-06-4024

Kucerova L, Feketeova L, Matuskova M, Kozovska Z, Janega P, Babal P, Poturnajova M, Cancer Lett. 335, 299-305, 2013. http:// dx.doi.org/10.1016/j.canlet.2013.02.040

Kucerova L, Kovacovicova M, Polak S, Bohac M, Fedeles J, Palencar D, Matuskova M, Neoplasma 58, 361-370, 2011a. http:// dx.doi.org/10.4149/neo $201105 \quad 361$

Kucerova L, Matuskova M, Hlubinova K, Altanerova V, Altaner C, Mol. Cancer 9, 1-15, 2010. http://dx.doi. org/10.1186/1476-4598-9-129

Kucerova L, Matuskova M, Hlubinova K, Bohovic R, Feketeova L, Janega P, Babal P, Poturnajova M, Cancer Lett. 311, 101-112, 2011b. http://dx.doi.org/10.1016/j. canlet.2011.07.014

Kucerova L, Matuskova M, Pastorakova A, Tyciakova S, Jakubikova J, Bohovic R, Altanerova V, Altaner C, J. Gene Med. 10, 1071-1082, 2008. http://dx.doi.org/10.1002/jgm.1239 
Kucerova L, Poturnajova M, Tyciakova S, Matuskova M, Stem Cell Res. 8, 247-258, 2012. http://dx.doi.org/10.1016/j. scr.2011.11.006

Ladd B, O'Konek JJ, Ostruszka LJ, Shewach DD, Cancer Gene Ther. 18, 751-759, 2011. http://dx.doi.org/10.1038/ cgt.2011.51

Lazennec G, Jorgensen C, Stem Cells 26, 1387-1394, 2008. http:// dx.doi.org/10.1634/stemcells.2007-1006

Le Blanc K, Tammik C, Rosendahl K, Zetterberg E, Ringdén O, Exp. Hematol. 31, 890-896, 2003. http://dx.doi.org/10.1016/ S0301-472X(03)00110-3

Maetzig T, Galla M, Baum C, Schambach A, Viruses 3, 677-713, 2011. http://dx.doi.org/10.3390/v3060677

Markowitz D, Goff S, Bank A, J. Virol. 62, 1120-1124, 1988.

Martiniello-Wilks R, Wang XY, Voeks DJ, Dane A, Shaw JM, Mortensen E, Both GW, Russell PJ, J. Gene Med. 6, 1343-1357, 2004. http://dx.doi.org/10.1002/jgm.629

Matuskova M, Baranovicova L, Kozovska Z, Durinikova E, Pastorakova A, Hunakova L, Waczulikova I, Nencka R, Kucerova L, J. Gene Med. 14, 776-787, 2012. http://dx.doi. org/10.1002/jgm. 2684

Matuskova M, Hlubinova K, Pastorakova A, Hunakova L, Altanerova V, Altaner C, Kucerova L, Cancer Lett. 290, 58-67, 2010. http://dx.doi.org/10.1016/j.canlet.2009.08.028

Menon LG, Shi VJ, Carroll RS, In Girard L (Eds): Mesenchymal stromal cells as a drug delivery system. Harvard Stem Cell Institute, Harvard University, pp. 1-14, 2009.

Mesnil M, Yamasaki H, Cancer Res. 60, 3989-3899, 2000.

Miller AD, In Coffin JM, Hughes SH, Varmus HE (Eds.): Development and applications of retroviral vectors. Retroviruses. Vol. 2. Cold Spring Harbor Laboratory Press, New York, 1997.

Minguell JJ, Erices A, Conget P, Exp. Biol Med. 226, 507-520, 2001.

Moolten FL, Cancer Res. 46, 5276-5281, 1986.

Morrison SJ, Wandycz AM, Hemmati HD, Wright DE, Weissman IL, Development 124, 1929-1239, 1997.

Myers TJ, Granero-Molto F, Longobardi L, Li T, Yan Y, Spagnoli A, Expert Opin. Biol. Ther. 10, 1663-1679, 2010. http:// dx.doi.org/10.1517/14712598.2010.531257

Najbauer J, Danks MK, Schmidt NO, Kim SU, Aboody KS, In Bertolotti R, Ozawa K (Eds): Neural stem cell-mediated therapy of primary and metastatic solid tumors. Progress in Gene Therapy, Autologous and Cancer Stem Cell Gene Therapy.Vol. 3. World Scientific, Singapore, pp. 335-372, 2007.

Piccoli C, Scrima R, Ripoli M, Di Ianni M, Del Papa B, D'Aprile A, Quarato G, Martelli MP, Servillo G, Ligas C, Boffoli D, Tabilio A, Capitanio N, Stem Cells 26, 2843-2854, 2008. http://dx.doi.org/10.1634/stemcells.2007-0885

Pittenger MF, Mackay AM, Beck SC, Jaiswal RK, Douglas R, Mosca JD, Moorman MA, Simonetti DW, Craig S, Marshak DR, Science 284, 143-147, 1999. http://dx.doi.org/10.1126/ science.284.5411.143

Porada CD, Almeida-Porada G, Adv. Drug Deliv. Rev. 62, 1156-1166, 2010. http://dx.doi.org/10.1016/j.addr.2010.08.010

Portsmouth D, Hlavaty J, Renner M, Mol. Aspects Med. 28, 4-41, 2007. http://dx.doi.org/10.1016/j.mam.2006.12.001
Prockop D, Science 276, 71-74, 1997. http://dx.doi.org/10.1126/ science.276.5309.71

Prockop DJ, Brenner M, Fibbe WE, Horwitz E, Le Blanc K, Phinney DG, Simmons PJ, Sensebe L, Keating A, Cytotherapy 12, 576-578, 2010. http://dx.doi.org/10.3109/14653249. 2010.507330

Ram Z, Culver K., Walbridge S, Frank JA, Blaese RM, Oldfield EH, J. Neurosurg. 79, 400-407, 1993. http://dx.doi.org/10.3171/ jns.1993.79.3.0400

Ranganath SH, Levy O, Inamdar MS, Karp JM, Cell Stem Cell 10, 244-258, 2012. http://dx.doi.org/10.1016/j. stem.2012.02.005

Reagan MR, Kaplan DL, Stem Cells 29, 902-927, 2011. http://dx.doi. org/10.1002/stem.645

Ringden O, Uzunel M, Rasmusson I, Le Blanc K, Transplantation 81, 1390-97, 2006. http://dx.doi.org/10.1097/01. tp.0000214462.63943.14

Roe T, Reynolds TC, Yu G, Brown PO, EMBO J. 12, 2099-2108, 1993.

Rosenberg SA, Blaese RM, Brenner MK, Deisseroth AB, Ledley FD, Lotze MT, Wilson JM, Nabel GJ, Cornetta K, Economou JS, Freeman SM, Riddell SR, Brenner M, Oldfield E, Gansbacher B, Dunbar C, Walker RE, Schuening FG, Roth JA, Crystal RG, Welsh MJ, Culver K, Heslop HE, Simons J, Wilmott RW, Boucher RC, Siegler HF, Barranger JA, Karlsson S, Kohn D, Galpin JE, Raffel C, Hesdorffer C, Ilan J, Cassileth P, O'Shaughnessy J, Kun LE, Das TK, Wong-Staal F, Sobol RE, Haubrich R, Sznol M, Rubin J, Sorcher EJ, Rosenblatt J, Walker R, Brigham K, Vogelzang N, Hersh E, Eck SL, Hum. Gene Ther. 11, 919-979, 2000. http://dx.doi.org/10.1089/10430340050015536

Scartozzi M, Maccaroni E, Giampieri R, Pistelli M, Bittoni A, Prete MD, Berardi1 R, Cascinu, Pharmacogenomics 12, 251-265, 2011. http://dx.doi.org/10.2217/pgs.10.167

Sheridan PL, Bodner M, Lynn A, Phuong TK, DePolo NJ, de la Vega DJ Jr, O'Dea J, Nguyen K, McCormack JE, Driver DA, Townsend K, Iba-ez CE, Sajjadi NC, Greengard JS, Moore MD, Respess J, Chang SM, Dubensky TW Jr, Jolly DJ, Sauter SL, Mol. Ther. 2, 262-275, 2000. http://dx.doi. org/10.1006/mthe.2000.0123

Spees JL, Olson SD, Ylostalo J, Lynch PJ, Smith J, Perry A, Peister A, Wang MY, Prockop DJ, Proc. Natl. Acad. Sci. USA 100, 2397-2402, 2003. http://dx.doi.org/10.1073/ pnas. 0437997100

Tai CK, Kasahara N, Front. Biosci. 13, 3083-3095, 2008. http:// dx.doi.org/10.2741/2910

Thust R, Tomicic M, Klocking R, Voutilainen N, Wutzler P, Kaina B, Cancer Gene Ther. 7, 107-117, 2000a. http://dx.doi. org/10.1038/sj.cgt.7700106

Thust R, Tomicic M, Klocking R, Wutzler P, Kaina B, Mutagenesis 15, 177-184, 2000b. http://dx.doi.org/10.1093/ mutage/15.2.177

Tolar J, Nauta AJ, Osborn MJ, Panoskaltsis Mortari A, McElmurry RT, Bell S, Xia L, Zhou N, Riddle M, Schroeder TM, Westendorf JJ, McIvor RS, Hogendoorn PC, Szuhai K, Oseth L, Hirsch B, Yant SR, Kay MA, Peister A, Prockop DJ, Fibbe WE, Blazar BR, Stem Cells 25, 371-379, 2007. http://dx.doi.org/10.1634/stemcells.2005-0620 
Tomicic MT, Thust R, Kaina B, Oncogene 21, 2141-2153, 2002. http://dx.doi.org/10.1038/sj.onc. 1205280

Tse WT, Pendleton JD, Beyer WM, Egalka MC, Guinan EC, Transplantation 75, 389-397, 2003. http://dx.doi. org/10.1097/01.TP.0000045055.63901.A9

Walther W, Stein U, Drugs 60, 249-271, 2000. http://dx.doi. org/10.2165/00003495-200060020-00002

Wollmann G, Tattersall P, Van Den Pol AN, J. Virol. 79, 60056022, 2005. http://dx.doi.org/10.1128/JVI.79.10.6005$\underline{6022.2005}$
Wygoda MR, Wilson MR, Davis MA, Trosko JE, Rehemtulla A, Lawrence TS, Cancer Res. 57, 1699-1703, 1997.

Yu SF, von Rüden T, Kantoff PW, Garber C, Seiberg M, Rüther U, Anderson WF, Wagner EF, Gilboa E, Proc. Natl. Acad. Sci. USA 83, 3194-3208, 1986. http://dx.doi.org/10.1073/ pnas.83.10.3194

Zhang Y, Parker WB, Sorscher EJ, Ealick SE, Curr. Top. Med. Chem. 5, 1259-1274, 2005. http://dx.doi. org/10.2174/156802605774463105 